The Future of Social Work 
Also by Terry Bamford

Managing Social Work 


\section{The Future of Social Work}

Terry Bamford

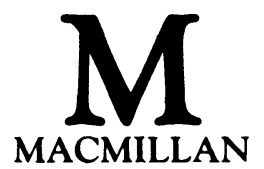


All rights reserved. No reproduction, copy or transmission of this publication may be made without written permission.

No paragraph of this publication may be reproduced, copied or transmitted save with written permission or in accordance with the provisions of the Copyright, Designs and Patents Act 1988, or under the terms of any licence permitting limited copying issued by the Copyright Licensing Agency, 90 Tottenham Court Road, London W1P.9HE.

Any person who does any unauthorised act in relation to this publication may be liable to criminal prosecution and civil claims for damages.

First published 1990 by

THE MACMILLAN PRESS LTD

Houndmills, Basingstoke, Hampshire RG21 2XS

and London

Companies and representatives

throughout the world

ISBN 978-0-333-46397-0

ISBN 978-1-349-20369-7 (eBook)

DOI 10.1007/978-1-349-20369-7

A catalogue record for this book is available

from the British Library.

Reprinted 1994 
To my parents and grandparents 


\section{Contents}

Acknowledgements

viii

Foreword

1 A Turbulent Environment 1

2 Practice in Flux 18

3 Unchanging Values? 41

4 Education and Training $\quad 65$

5 Organisation and Structure $\quad 86$

6 The Development of Managerialism 108

7 Health and Social Services: Partners or Rivals? 128

8 Towards the Twenty-First Century 149

$\begin{array}{ll}\text { Bibliography } & 171\end{array}$

Index 177 


\section{Acknowledgements}

Writing a book is a very personal undertaking but in the process one incurs many debts of gratitude. The initial idea for a book which would both look forward but set that in the context of recent social work history came from Jo Campling and Steven Kennedy. I am grateful to them for their encouragement, continuing support and wise counsel as the book took shape.

The ideas were shaped by many individuals who unwittingly provided stimulus and inspiration. Two in particular deserve special recognition. Joan Cooper provided detailed and helpful comments which were invaluable. Stuart Etherington's robust enthusiasm for the development of welfare pluralism was invigorating. Without knowing it he provided the spur to put pen to paper.

Participation is a recurrent theme of the book. I have greatly valued the opportunity to be involved in active creative and thoughtful professional associations like BASW and ADSS and that too has influenced my thinking.

The staff of the Southern Health and Social Services Board have provided me with the opportunity to explore new ideas, and have consistently displayed an openness to innovation and a creativity which represents all that is best in social work. To all of them I am grateful. To my patient secretary, Anne Nethercote, go my special thanks for her help in getting the manuscript into a legible state.

The author and publishers acknowledge with thanks the permission of CCETSW to reproduce Figure 4.1 and of the Audit Commission to reproduce Figure 5.1 and Table 5.1 from Making Reality of Community Care.

Finally but most important of all I thank my family - Margaret, Andrew and Sarah - for their patience, forbearance and encouragement without which the book would never have been completed. 


\section{Foreword}

Anyone rash enough to take as a title The Future of Social Work invites the response that there should be a question mark after the title. Twenty years after the Seebohm Report social work has failed to establish its independent professional status, has a basic training shorter than that of the other occupational groups involved in community care, and has dropped precipitately in public esteem. Its organisational future too is uncertain, threatened by the Government's unremitting hostility to local government.

It is hard now to remember the sense of optimism, the belief in the capacity of social work to make a real impact on the lives of the vulnerable, disadvantaged, and disturbed, that characterised the time between the publication of the Seebohm Report and the advent of social services departments. Scotland had moved earlier with the creation of social work departments, and organisational change seemed to promise both an increase in resources for social care and a commitment to combating deprivation.

What went wrong? How did that rich promise so swiftly become tarnished? What lessons can be drawn from the recent history of social work in Britain? To influence the future it is first necessary to understand the past. The collective memory of social work is notoriously short and its pursuit of currently fashionable nostrums correspondingly uncritical. A sense of history is a useful corrective to such ephemeral enthusiasms.

The history offered here is brief and selective. It focuses upon the years following the publication of the Seebohm Report because they marked a turning-point in the scale of social welfare provision and established the framework for contemporary social work and its organisation. By identifying emerging trends in practice and organisation, and by a study of the sometimes opaque 
pattern of Government thinking, one can begin to construct a view of the likely future.

The view offered is a personal view. By the date of publication some of the issues canvassed may be on the way to resolution but the focus of the book is on those issues where change takes decades rather than months. These are the relevance of structure and organisation both to public perception and professional satisfaction, the lack of a strong professional identity in social work, and the implications of consumerism for the future provision of social work.

\section{Size and Structure}

There was a common strand in social policy developments when the Seebohm Report was published, and in the years of its implementation. It was the shared belief that bigger meant better, whether in the creation of super-ministries at Governmental level, the reorganisation of local government and its services or the restructuring of industry. Economies of scale would produce greater efficiency. Large-scale enterprises would attract and retain talent. In social work the initial reorganisation in 1971 into multipurpose departments was succeeded by the 1974 reorganisation of local government, further compounding the move to large-scale units of organisation.

The effects on social work have been predominantly negative. While there have been significant advances in resource provision, these have been concentrated in residential and day care services. Those services most visible to the consumer - fieldwork and domiciliary services - have not expanded as rapidly. Nearly twenty years after the first unified departments came into being, 'the welfare' is still more real to many clients than the designation 'social services'. And both share the characteristic of an impersonal bureaucratic machine over which clients exercise little influence.

The turnover of staff, the layers of managerial control and the absence of clearly-identified personal responsibility have combined to create a sense of public unease about the effectiveness of welfare provision. That has been reinforced by the highly publicised child-care tragedies and the failure of successive inquiries to 
produce a scapegoat to satisfy the public's concern. The reporting of these cases has tended to confirm and reinforce the stereotype of self-protective structures in which responsibility is blurred. Paradoxically that perception is shared by many within social work who regret the decline in personal accountability, and see the structures of social services departments as stifling creativity, initiative and good practice.

The lack of a practitioner career structure within social work reflects the differential values accorded to skilled practice and managerial responsibility. It means that the most able practitioners are promoted away from client contact as organisational imperatives are accorded precedence over the quality of service enjoyed by individual clients.

Redressing the problems created by size will be a preoccupation of the nineties. At one extreme are the radical prescriptions of the ideologues of the market, who would cheerfully see the dismemberment of direct public sector provision and the emergence of a host of competing providers. Such diversity, while addressing the issues of impersonal bureaucracy, would produce other problems in terms of duplication, overlapping provision and geographical variations in volume and quality of service. At the other extreme, those who foresee a continuation of the existing or even enhanced role of social services departments acknowledge the importance of improving access, communication and consultation for and with clients.

\section{An Uncertain Profession}

The implementation of the Seebohm recommendations should have been the launch-pad for a consolidation of the social work profession. Instead, the failure of social work to achieve its professional aspirations of self-regulation in terms of training and disciplinary action against professional failings encapsulated the failure of social work as a whole to reach agreement on its role and function.

The social work strikes in 1977 and 1978 epitomised the dilemma. In pursuance of a grievance related to pay and conditions, social workers took strike action in a significant number of local authorities. Their actions did little damage to the employing 
authorities and the damage to clients was hard to identify or quantify. The action was most effective in its symbolic repudiation of traditional concepts of professionalism based on the primacy of service to clients.

There is in social work a widespread agreement about the irrelevance of models of professionalism based on the established professions of the law and medicine. The commitment of social workers to change in society and to redressing the inequalities and injustices which they see daily leads to justified anger at the deficiencies of existing social systems. Anger, however, is no substitute for thought. Too often social workers have substituted the emotional spasm of solidarity with the working class for careful analysis. Political identity has been more important than professional identity.

Two examples of this tendency can be offered - both have operated to the detriment of social work's attempt to establish its role in society. First, there is a deeply ingrained ambivalence about training and qualifications even among those who possess them or teach on courses which provide them. It finds expression in suspicion of 'elitism', in a repudiation of the view that some can be better equipped by training and experience to fulfil social work roles than others with a kindly disposition but lacking formal qualifications. This is a spurious egalitarianism which has consistently undermined the admittedly half-hearted attempts of the Central Council for Education and Training in Social Work to establish a graduated hierarchy of qualifications.

Second, some social workers believe that the task of social control is not one for social workers but for the police. The reality is, however, that social workers as employees of the state are employed to undertake specific tasks. Unarticulated but implicit in that employment is the belief of the employers that the provision of welfare services is a contributory factor to the maintenance of public stability. When social workers become involved with the mentally-disordered individual presenting florid symptoms, or the disturbed adolescent, or the child at risk, they are not acting as the representatives of the altruistic impulses of society. They are being paid to quieten the situation, to relieve anxiety, and to exercise some control over a situation in which the normal mechanisms of control had broken down. There is nothing dishonourable about an honest recognition that social workers are in a social control 
role. The difficulties come when that reality is denied as if social workers were indeed a self-regulating group of independent contractors. Asserting a higher professional obligation to the welfare of the client is untenable if the other indicators of professional status are absent.

These self-contradictory attitudes are widely held and have contributed to the inability of the British Association of Social Workers to exercise a major role over the development of social work in Britain. There are some grounds for suggesting that the 1990s will see a reversion to professionalism. First the far more differentiated employment market likely to emerge in an age of welfare pluralism will break the power of local authorities as virtual monopolistic providers of social work employment. As employers local authorities have been as hostile to the development of a vigorous independent professionalism as have trade unions. The erosion of their influence and the desire of employees in small welfare agencies to have an external reference point for good practice may lead to a resurgence of interest in professional bodies, as happened in the USA with the decline in public sector provision and the development of alternative providers.

Second, the closer linkages with health care workers will focus attention on the anomalous position of social work as the lone skilled occupational group without some form of registration and quality control. Third, the demographic shift now taking place, with the decline in the working population, will force social work into a role orchestrating support workers of various kinds. There will not be sufficient staff available of the calibre required to maintain present employment patterns.

The response which social work makes to these trends will depend on the degree to which it can incorporate the values being expressed under the banner of consumerism.

\section{The New Consumerism}

Consumerism is one of those rare concepts that does not automatically carry a political label of Right or Left. The emphasis on freedom of choice is appealing to the Right, the extension of user power is attractive to the Left. Yet despite the calls in both the Seebohm and Barclay Reports for greater attention to ways in 
which the community could be involved in personal social services, relatively little has been achieved in shifting the balance of power between providers of service and consumers.

There are some hopeful signs in shifts which have begun to take root in recent years. The development of increased client-access to files, the emphasis on parental rights to information and to be heard in case-conferences affecting their children's future, moves to decentralise services and to secure community participation, the growth of advocacy schemes offering a voice to those who have been powerless, legislative provision strengthening the rights of carers to be consulted - and the growing acceptance of the concept that services are a right and not in the discretionary gift of the provider, are indicative of a major paradigm shift from the producer-orientation which has hitherto dominated the welfare services.

Some of those changes have been enthusiastically espoused by social workers. Others have been viewed with suspicion as making the already difficult task of the worker even more complex. The future of social work is critically dependent on its ability and readiness to harness the new consumerism and to work with it. In assessing whether this is likely to occur, it is important to go back to the basic values of social work and test them against the demands of a consumer orientation. What one finds is a striking congruence between the long-established value statements of the profession expressed in Codes of Ethics and the aspirations of the contemporary consumer.

The concept of citizenship is one which directs attention to the rights of clients as fellow-citizens. The social worker respecting those rights has to ensure that the clients have full access to all relevant information, are aware of rights to see the case record, to register complaints, and to appeal against decisions. The concept of empowerment is not new. It is firmly enshrined in the notion of client self-determination which has been a central social work value for half a century. What is new is the increased readiness of social workers to give reality to what was formerly an abstract principle. If this can be further developed, the transfer of power and responsibility to service-users may constitute a professional radicalism far more persuasive and influential on clients' lives than the blind alley of a political radicalism has proved.

One of the challenges facing all welfare services will be the 
establishment of appropriate skills, knowledge and structures to deliver effective services to ethnic minorities. Participation of minorities and real control in shaping those services is essential if the concept of citizenship is to be non-racist.

While the future holds uncertainties and the likelihood of major change, it is not a prospect which need be feared by social workers. The consumerist thrust of current developments has to be matched by a new professionalism, emphasising rights and power for clients. While there is a latent tension between social control and empowerment this will be eased by the development of more differentiated patterns of employment. The values of social work, which have been too long been subjugated by the dominant role of the employing agency, will again mould a practice which is flexible, creative and fulfilling. Romantic nonsense? Maybe so, but the future is not predetermined. It will be influenced by those bold enough to look beyond immediate time horizons and able to convey a vision of the future they want to achieve. Hitherto, social work, preoccupied with present problems, has failed to do so. This book is a modest contribution to that endeavour. 